\title{
PENGARUH MODEL CONCEPTUAL UNDERSTANDING PROCEDURES TERHADAP PENGUASAAN KONSEP DAN KEMAMPUAN PEMECAHAN MASALAH FISIKA PESERTA DIDIK KELAS X SMAN 1 GERUNG
}

\author{
Nurul Hidayah, Sutrio, Hikmawati* \\ Program Studi Pendidikan Fisika, Universitas Mataram \\ *Email: hikmawati@unram.ac.id
}

DOI: http://dx.doi.org/10.29303/jpft.v5i1.777

\begin{abstract}
Quasi experimental research with "non-equivalent control group design" aims to determine the effect of conceptual understanding procedures model on the mastery of concepts and ability to solve the physics problems of class X students SMAN 1 Gerung tahun 2017/2018. Population in this research is all students of class X MIPA SMAN 1 Gerung with sampling technique using purposive sampling, so selected class X MIPA 2 as experiment class and class X MIPA 5 as control class. Data collection of the mastery of concepts was performed using multiple choice test with mean score for experimental class of 72,96 and for control class equal to 63,29 and problem solving ability using essay test with mean value for experiment class was 56,30 and for the control class of 44.48. After the teaching, the mastery of the concepts of both classes increased, the second highest grade values occurred in the mechanical energy sub-material with the percentage of $69 \%$ in the experimental class and $66 \%$ in the control class whereas the second lowest grade occurred on the restoring force sub-material. Problem-solving abilities (PSAs) were 6 indicators, in the control class PSA-1 higher than the experimental class, while the PSA-2 through the PSA-6 experimental class was higher than the control class. The hypothesis of this study was tested by the test-t polled variance with a significant level of $5 \%$ and obtained t count of 4.65 for the mastery of concepts and t count of 3.50 for problem-solving abilities while the table value of 1.99 means $t$ count more great from $t$ table. The results of this study indicate that there is influence conceptual understanding procedures model to the mastery of the concept and ability of solving physics problems of students class X SMAN 1 Gerung academic year 2017/2018.
\end{abstract}

Keywords: Problem-solving abilities, conceptual understanding procedures.

\section{PENDAHULUAN}

Berdasarkan hasil observasi beberapa kelas X di SMA Negeri 1 Gerung masih banyak permasalahan yang dialami dalam pembelajaran fisika. Permasalahan yang terjadi antara lain peserta didik menganggap pelajaran fisika merupakan pelajaran yang kurang menarik, sulit dipahami, dan sangat membosankan karena banyak hitungan sehingga menyebabkan prestasi peserta didik dalam pelajaran fisika kurang memuaskan. Peserta didik juga menganggap bahwa pelajaran fisika merupakan pelajaran yang identik dengan rumus dan penuh dengan hafalan yang sulit dimengerti atau dinalar. Hal tersebut mengakibatkan peserta didik cenderung pasif dan bosan serta tidak memiliki keberanian dalam mengajukan pertanyaan dan kurang mampu dalam mengutarakan ide. Permasalahan tersebut dapat terlihat jika dikaitkan dengan pola belajar peserta didik dalam memahami fisika, peserta didik lebih terfokus pada rumus yang digunakan untuk memecahkan permasalahan fisika tanpa memaknai konsep yang mendasarinya. Ketika konsep fisika diterapkan pada situasi atau permasalahan yang baru bahwa peserta didik tidak mampu menjawab permasalahan tersebut. Selain itu, ketika konsep fisika selesai dipelajari, kemudian ditanyakan pada waktu yang berbeda, peserta didik tidak mampu mengingat kembali apa yang sudah dipelajari karena pengetahuan yang selama ini dimiliki peserta didik hanya bersifat hapalan.

Kondisi minimnya keterampilan berpikir peserta didik untuk memecahkan masalah fisika dan sulitnya peserta didik untuk mengingat pelajaran yang telah lalu 
memerlukan adanya upaya perbaikan. Dengan meningkatkan kemampuan peserta didik memecahkan masalah fisika diharapkan dapat menjadi solusi untuk meningkatkan penguasaan konsep peserta didik dalam pembelajaran fisika. Salah satu model pembelajaran yang tepat untuk menangani permasalahan di atas adalah model Conceptual Understanding Procedures (CUPs).

Menurut Mills et al. (1999), model pembelajaran conceptual understanding procedures adalah prosedur pengajaran yang melibatkan peserta didik dalam diskusi tentang masalah fisika yang dikaitkan dalam konteks dunia nyata (kontekstual) (dalam Fitriani et al. 2017).

Gustone et al. (2009) menyatakan model pembelajaran conceptual understanding procedures merupakan model pembelajaran yang terdiri atas serangkaian kegiatan (prosedur-prosedur) pembelajaran dan bertujuan untuk meningkatkan pemahaman konsep peserta didik (dalam Ismawati et al. 2014). Menurut Prastiwi et al. (2014), model pembelajaran conceptual understanding procedures merupakan model pembelajaran yang dirancang untuk membantu perkembangan pemahaman peserta didik menemukan konsep yang sulit. Ismawati et. al. (2014:23) menyatakan model CUPs dibangun atas tiga fase, yaitu (1) fase individu; (2) fase kerja kelompok; dan (3) fase presentase.

Penelitian sebelumnya yang terkait dengan model CUPs seperti yang dilakukan oleh Gummah et al. (2014) membuktikan bahwa melalui penerapan model pembelajaran kooperatif teknik Conceptual Understanding Procedures (CUPs) dapat meningkatkan hasil belajar dan aktivitas peserta didik kelas VIII SMP Negeri 13 Mataram. Begitu pula dengan hasil penelitian yang telah dilakukan Ibrahim et al. (2017) menyatakan bahwa ada perbedaaan siginifikan akibat pengaruh model pembelajaran Conceptual Understanding Procedures (CUPs) berbantuan LKPD terhadap kemampuan pemecahan masalah fisika.

Tujuan dalam penelitian adalah untuk mengetahui: (1) Pengaruh model pembelajaran conceptual understanding prosedures terhadap penguasaan konsep fisika peserta didik kelas X SMA Negeri 1 Gerung tahun ajaran 2017/2018; (2) Pengaruh model pembelajaran conceptual understanding prosedures terhadap kemampuan pemecahan masalah fisika peserta didik kelas X SMA Negeri 1 Gerung tahun ajaran 2017/2018.

\section{METODE PENELITIAN}

Jenis penelitian yang digunakan adalah kuasi eksperimen atau eksperimen semu Setyosari (2015). Desain penelitian yang digunakan adalah Nonequivalent Control Group Desain (Sugiyono, 2013). Variabel adalah segala sesuatu yang menjadi objek pengamatan dalam penelitian dan jika diukur memiliki variasi (Setyosari, 2015). Variabel bebas pada penelitian ini adalah model pembelajaran CUPs. Variabel terikat pada penelitian ini adalah penguasaan konsep dan kemampuan pemecahan masalah fisika peserta didik. Variabel kontrol pada penelitian ini adalah guru, materi ajar yaitu getaran harmonis, alokasi waktu kegiatan belajar mengajar, instrumen tes penguasaan konsep dan kemampuan pemecahan masalah, serta cara penilaian yang dikondisikan sama baik pada kelas eksperimen maupun kelas kontrol.

Pengambilan data dalam penelitian ini dilakukan pada bulan April hingga Mei 2018 di SMAN 1 Gerung. Populasi pada penelitian ini adalah seluruh peserta didik kelas X MIPA SMAN 1 Gerung yang terbagi menjadi 6 kelas berjumlah 200 peserta didik. Sampel pada penelitian ini adalah peserta didik kelas X MIPA 2 sebagai kelas eksperimen dan peserta didik kelas X MIPA 
5 sebagai kelas kontrol yang diperoleh melalui teknik purposive sampling.

Instrumen yang digunakan dalam penelitian ini berupa instrumen tes (Sahidu, 2016). Bentuk tes tertulis yang digunakan adalah tes pilihan ganda untuk mengetahui penguasaan konsep peserta didik dan tes uraian untuk mengetahui kemampuan pemecahan masalah fisika. Uji coba tes ini dilakukan pada kelas XI MIPA 7 SMAN 1 Gerung. Sebelum instrumen soal digunakan pada kedua kelompok sampel, terlebih dahulu dilakukan menghitung validitas, reliabilitas, daya beda, dan taraf kesukarannya.

Tes kemampuan pemecahan masalah dalam penelitian ini dalam bentuk soal uraian. Penilaian yang digunakan berdasarkan 6 indikator menurut Solso (2007) yaitu identifikasi permasalahan, representasi atau penyajian permasalahan, perencanaan pemecahan, menerapkan atau mengimplementasikan perencanaan, menilai perencanaan, dan menilai hasil pemecahan (dalam Wena, 2014:56). Uji validitas pada instrumen soal kemampuan pemecahan masalah menggunakan uji validitas oleh para ahli.

Data yang telah diperoleh dari hasil tes penguasaan konsep dan kemampuan pemecahan masalah, selanjutnya dianalisis dengan menggunakan uji homogenitas, uji normalitas, uji hipotesis (Sugiyono, 2012:140) dan uji N-gain. (Hake dalam Sundayana, 2015:151).

\section{HASIL DAN PEMBAHASAN}

Data kemampuan awal yang digunakan dalam penelitian in adalah data hasil dari tes awal (pre-test) peserta didik sebelum diberikan perlakuan diperoleh ratarata kemampuan awal kelas eksperimen lebih tinggi dari pada kelas kontrol, yaitu rata-rata nilai tes awal kelas eksperimen 28,44 dan rata-rata nilai tes awal kelas kontrol 22,76.
Data kemampuan akhir yang digunakan dalam penelitian adalah data hasil dari tes akhir peserta didik setelah diberikan perlakuan.Tes akhir di berikan untuk mengetahui homogenitas, normalitas dan hipotesis penelitian. Adapun hasil tes akhir diperoleh bahwa nilai tertinggi terdapat pada kelas eksperimen yaitu 88 sedangkan kelas kontrol 85. Dengan rata-rata nilai kelas eksperimen 72,96 dan rata-rata nilai kelas kontrol 63,29.

Uji homogenitas hasil tes akhir dilakukan untuk menentukan tindak lanjut dari $t$-test yang akan digunakan. Dari hasil perhitungan diperoleh bahwa $F_{\text {hitung }}(1,06)$ $<F_{\text {Tabel }} \quad(1,76)$. Berdasarkan kriteria pengambilan keputusan, maka kedua sampel berasal dari populasi yang homogen. Dengan demikian, uji $\mathrm{t}$ yang digunakan adalah $t$-test pooled varian.

Uji normalitas data dilakukan untuk menentukan jenis statistik yang digunakan. Selain itu, uji normalitas juga berfungsi untuk mengetahui normal atau tidak normal data kelas eksperimen dan data kelas kontrol. Hasil uji normalitas data tes awal dan tes akhir untuk kelas eksperimen dan kelas kontrol menunjukkan bahwa $X_{\text {hitung }}^{2}$ lebih kecil dari $X_{\text {tabel }}^{2}$. Hal ini berarti data penelitian berasal dari populasi yang terdistribusi normal. Berdasarkan hasil tersebut, statistik yang digunakan adalah statistik parametrik.

Uji normalized gain (Uji N-Gain) dilakukan bertujuan untuk mengetahui tingkat signifikansi peningkatan penguasaan konsep setiap materi getaran harmonis fisika peserta didiksetelah diberikan perlakuan. Materi getaran harmonis yang dijadikan bahan dalam penelitian ini dibatasi hanya 4 sub materi yang meliputi gaya pemulih pada getaran harmonis, periode dan frekuensi pada getaran harmonis, besaran-besaran fisis pada getaran harmonis, dan energi mekanik pada getaran harmonis. Analisis uji N-gain 
pada penelitian ini ditinjau berdasarkan perolehan nilai masing-masing peserta didik pada setiap sub materi. Nilai N-gain pada sub materi di kelas eksperimen cenderung memiliki nilai lebih tinggi dibandingkan kelas kontrol.

Berdasarkan hasil uji prsayarat analisis, diperoleh bahwa data tes akhir kelas eksperimen dan kelas kontrol terdistribusi normal dan memiliki varians yang homogen, sehingga uji statistik yang digunakan adalah statistik parametrik t-test pooled varian. Hasil uji hipotesis diperoleh $t_{\text {hitung }}=4,65$ dan $t_{\text {Tabel }}=1,99$ pada taraf signifikansi $5 \%$ dengan derajat kebebasan $64\left(d k=n_{1}+\right.$ $\left.n_{2}-2=33+33-2=64\right) . \quad$ Nilai $t_{\text {hitung }}>t_{\text {Tabel }}$ yaitu $4,65>1,99$, maka $\mathrm{Ho}_{1}$ ditolak dan $\mathrm{Ha}_{1}$ diterima. Jadi terdapat pengaruh model CUPs terhadap penguasaan konsep fisika peserta didik kelas X SMAN 1 Gerung.

Peningkatan antara kedua kelas terjadi perbedaan yang signifikan. Peningkatan penguasaan konsep pada sub materi meningkat dari sub materi pertama sampe sub materi terakhir. Jadi, peningkatan penguasaan konsep yang tertinggi terdapat pada sub materi terakhir. Hal ini dapat dilihat persentase peningkatan pada kelas eksperimen sebesar 50\% dan kelas kontrol sebesar $35 \%$ pada sub materi gaya pemulih pada getaran harmonis. Pada sub materi periode dan frekuensi pada getaran harmonis persentase peningkatan sebesar 55\% untuk kelas eksperimen dan untuk kelas kontrol sebesar $47 \%$. Pada sub materi besaranbesaran fisis pada getaran harmonis persentase peningkatan sebesar $67 \%$ untuk kelas eksperimen dan untuk kelas kontrol sebesar 57\%. Untuk materi terakhir pada sub materi energi mekanik pada getaran harmonis peningkatan persentase sebesar $69 \%$ untuk kelas eksperimen dan untuk kelas kontrol sebasar 66\%. Perbedaan peningkatan pada semua sub materi yang cukup signifikan tersebut disebabkan karena di kelas eksperimen menerapkan model conceptual understanding procedures (CUPs), karena model ini lebih berperan aktif peserta didik dalam proses pembelajaran. Pembelajaran CUPs memiliki tiga fase, yaitu fase kerja individu, fase kerja kelompok dan fase presentasi hasil kerja kelompok, dimana pada setiap fase tersebut memberi kesempatan pada peserta didik untuk berperan aktif secara langsung dalam proses pembelajaran.

Adapun penelitian sebelumnya yang mendukung penelitian ini oleh Ismawati et al. (2014), model pembelajaran conceptual understanding procedures (CUPs) terbukti dapat meningkatkan pemahaman konsep peserta didik SMP pada pelajaran fisika, dan lebih efektif dibandingkan model pembelajaran verifikasi. Menurut Wulandari et al. (2017), model conceptual understanding procedures terbukti dapat meningkatkan hasil belajar fisika peserta didik kelas XI SMA Negeri 5 Mataram tahun ajaran 2015/2016. Hidayati \& Sinulingga (2015:65) menyatakan bahwa penerapan model pembelajaran Conceptual Understanding Procedures (CUPs) dapat meningkatkan ada hasil belajar peserta didik pada materi pokok listrik dinamis di kelas X. Hasil penelitian tersebut membuktikan bahwa penggunaan model pembelajaran Conceptual Understanding Procedures (CUPs) dalam pembelajaran berpengaruh positif terhadap penguasaan konsep fisika peserta didik.

Data tes awal Kemampuan Pemecahan Masalah yang digunakan dalam penelitian ini adalah data hasil dari tes awal (pre-test) peserta didik sebelum diberikan perlakuan. Hasil tes awal menunjukkan bahwa nilai rata-rata kemampuan awal kelas eksperimen lebih tinggi dari pada kelas kontrol. Nilai tertinggi terdapat pada kelas eksperimen yaitu 53 sedangkan kelas control 45 , sedangkan untuk nilai terendah pada 
kelas eksperimen adalah 18 dan pada kelas kontrol 16. Dengan rata-rata nilai kelas eksperimen 33,76 dan rata-rata nilai kelas kontrol 29,18.

Data kemampuan akhir yang digunakan dalam penelitian ini adalah data hasil dari tes akhir peserta didik setelah diberikan perlakuan. Tes akhir diberikan untuk mengetahui homogenitas, normalitas dan hipotesis penelitian. Adapun hasil perhitungan tes akhir menunjukkan bahwa nilai tertinggi terdapat pada kelas eksperimen yaitu 84 sedangkan kelas control 72, sedangkan untuk nilai terendah pada kelas eksperimen adalah 31 dan pada kelas kontrol 20. Dengan rata-rata nilai kelas eksperimen 56,30 dan rata-rata nilai kelas kontrol 44,48.

Uji homogenitas hasil tes awal bertujuan untuk mengetahui apakah peserta didik kelas eksperimen dan peserta didik kelas kontrol memiliki kemampuan awal yang sama. Uji homogenitas hasil tes akhir dilakukan untuk menentukan tindak lanjut dari t-test yang akan digunakan. Hasil uji homogenitas tes awal dan tes akhir kemampuan pemecahan masalah pada kelas eksperimen dan kelas kontrol menunjukkan Bahwa $F_{\text {hitung }}<F_{\text {Tabel }}$. Berdasarkan kriteria pengambilan keputusan, maka kedua sampel berasal dari populasi yang homogen. Dengan demikian, uji $\mathrm{t}$ yang digunakan adalah $t$-test pooled varian.

Uji normalitas data dilakukan untuk menentukan jenis statistik yang digunakan. Selain itu, uji normalitas juga berfungsi untuk mengetahui normal atau tidak normal data kelas eksperimen dan data kelas kontrol. Hasil uji normalitas data untuk tes kemampuan pemecahan masalah menunjukkan bahwa $X_{\text {hitung }}^{2}$ lebih kecil dari $X_{\text {tabel }}^{2}$, pada derajat kebebasan 5 dan taraf signifikansi 5\%. Hal ini berarti data penelitian berasal dari populasi yang terdistribusi normal. Berdasarkan hasil tersebut, statistik yang digunakan adalah statistik parametrik.

Uji normalized gain (Uji N-Gain) dilakukan bertujuan untuk mengetahui tingkat signifikansi peningkatan kemampuan pemecahan masalah fisika setiap indikator. Indikator kemampuan pemecahan masalah meliputi mengidentifikasi masalah, menyajikan permasalahan, merencanakan pemecahan, menerapkan perencanaan, menilai perencanaan dan menilai hasil pemecahan masalah. Analisis uji $\mathrm{N}$-gain tiap indikator kemampuan pemecahan masalah menunjukkan bahwa nilai $\mathrm{N}$-gain pada indikator kelas eksperimen cenderung memiliki nilai lebih tinggi dibandingkan kelas kontrol kecuali pada indikator mengidentifikasi masalah. Nilai $\mathrm{N}$-gain yang lebih tinggi mengindikasikan adanya peningkkatan. Berdasarkan hasil uji prsayarat analisis, diperoleh bahwa data tes akhir kemampuan pemecahan masalah fisika pada peserta didik kelas eksperimen dan kelas kontrol terdistribusi normal dan memiliki varians yang homogen, sehingga uji statistik yang digunakan adalah statistik parametrik $t$-test pooled varian. Berdasarkan hasil perhitungan diperoleh $t_{\text {hitung }}=3,50$ dan $t_{\text {tabel }}=1,99$ pada taraf signifikansi 5\% untuk derajat kebebasan 64. Dengan demikian nilai $t_{\text {hitung }}>t_{\text {Tabel }}$ yaitu 3,50>1,99, maka $\mathrm{Ho}_{2}$ ditolak dan $\mathrm{Ha}_{2}$ diterima. Jadi terdapat pengaruh model conceptual understanding procedures terhadap kemampuan pemecahan masalah fisika peserta didik kelas X SMAN 1 Gerung.

Penerapan model pembelajaran conceptual understanding procedures (CUPs) pada kelas eksperimen dapat meningkatkan pemecahan masalah fisika yang cukup signifikan. Hal ini disebabkan karena didalam fase pembelajaran, setelah guru memberikan penjelasan, peserta didik melakukan pelatihan dengan mengerjakan 
soal kerja individu. Penjelasan dari soal kerja individu berisi tentang fenomena/masalah yang sederhana yang dapat membangkitkan motivasi peserta didik tersebut. Pada fase berikutnya yaitu fase kerja kelompok, di fase ini peserta didik bekerja sama dengan anggota kelompoknya masing-masing untuk mengerjakan lembar kerja kelompok yang berisi tentang praktikum dan berbagai pertanyaan yang harus diselesaikan oleh peserta didik tersebut, sedangakan untuk fase terakhir yaitu fase persentasi, dimana fase persentasi ini masing-masing kelompok mempersentasikan hasil praktikum dan diskusi disampaikan perwakilan kelompok di depan kelas dan ditanggapi oleh kelompok lain. Sehingga disamping peserta didik dapat menguasai konsep, peserta didik juga memiliki kemampuan dalam memecahkan masalah dikehidupan nyata yang ada kaitannya dengan fisika, khususnya untuk materi Getaran Harmonis.

Perolehan skor kemampuan pemecahan masalah juga di analisis uji $\mathrm{N}$ gain tiap indikator. Hasil persentase peningkatan setiap indikator kemampuan pemecahan masalah bahwa kelas kontrol mengalami peningkatan sebesar $5 \%$ pada indikator 1 , sedangkan untuk indikator 2 sampai indikator 6 untuk kelas eksperimen mengalami peningkatan yang lebih tinggi daripada kelas kontrol. Dari hasil tersebut juga pada indikator 1 sampai indikator 4 tidak terdapat perbedaan yang signifikan antara kedua kelas.

Hal ini berarti kemampuan peserta didik dalam mengidentifikasi masalah, menyajikan permasalahan, merencanakan pemecahan, dan menerapkan perencanaan untuk kedua kelas hampir sama, sedangkan untuk hasil indikator 5 dan indikator 6 terdapat perbedaan yang cukup signifikan antara kedua kelas. Dengan demikian, indikator 5 (menilai perencanaan) dan indikator 6 (menilai hasil pemecahan masalah) lebih baik dialami oleh peserta didik di kelas eksperimen dari pada kelas kontrol.

Perbedaan peningkatan pada setiap indikator kemampuan pemecahan masalah yang cukup signifikan tersebut disebabkan karena di kelas eksperimen menerapkan model conceptual understanding procedures (CUPs), karena model ini menekankan keaktifan dalam setiap fase pembelajaran. Pembelajaran CUPs memiliki tiga fase, yaitu fase kerja individu, fase kerja kelompok dan fase presentasi hasil kerja kelompok, dengan mengaktifkan peserta didik secara langsung bahwa peserta didik sudah mampu memahami konsep-konsep fisika sehingga peserta didik lebih mudah dalam menyelesaikan masalah-masalah fisika pada materi getaran harmonis.

Adapun hal-hal yang perlu dilakukan untuk upaya meningkatkan kemampuan pemecahan masalah pada indikator 1 yang berisi tentang bagaiamana peserta didik mengidentifikasi suatu masalah dan untuk indikator 3 yang berisi tentang bagaimana peserta didik menerapkan pemecahan masalah, karena pada indikator 1 dan indikator 3 memiliki perbedaan yang kurang siginifikan dari kedua kelas tersebut dibandingkan dengan indikator yang lain. Oleh karena itulah, harus melakukan penekanan-penekanan pada saat pembelajaran dalam hal membedakan antara akibat-akibat yang dapat terjadi dari suatu penyebab. Selain itu, menentukan konsep, prinsip, teori, dan atau hukum fisika yang digunakan untuk mendukung dalam mengidentifikasi sebuah atau beberapa penyebab sehingga menghasilkan suatu akibat. Kemudian bagaimana peserta didik dapat menerapkan konsep, prinsip, teori, dan atau hukum fisika tersebut, serta dapat mengidentifikasi bagaimana kondisi penyebab tersebut dapat menghasilkan suatu akibat. Dengan demikian kemampuan 
pemecahan masalah peserta didik dapat utuh secara keseluruhan.

Adapun penelitian sebelumnya yang mendukung penelitian ini oleh Ibrahim et al. (2017) menyatakan bahwa penggunaan model conceptual understanding procedures (CUPs) berbantuan LKPD terbukti dapat meningkatkan kemampuan pemecahan masalah fisika peserta didik kelas XI. Menurut Fitriani et al. (2017), model pembelajaran conceptual understanding procedures berbantuan LKPD terbukti dapat meningkatkan kemampuan berfikir kreatif fisika peserta didik kelas X pada materi suhu dan kalor.

\section{PENUTUP}

Berdasarkan hasil penelitian dan pembahasan yang telah dipaparkan, maka dapat disimpulkan bahwa: (1) Terdapat pengaruh model pembelajaran Conceptual Understanding Procedures (CUPs) terhadap penguasaan konsep fisika peserta didik kelas $\mathrm{X}$ SMA Negeri 1 Gerung tahun ajaran 2017/2018; (2) Terdapat pengaruh model pembelajaran Conceptual Understanding Procedures (CUPs) terhadap kemampuan pemecahan masalah fisika peserta didik kelas X SMA Negeri 1 Gerung tahun ajaran $2017 / 2018$

\section{REFERENSI}

Fitriani, N., Gunawan, G., \& Sutrio, S. 2017. Berfikir Kreatif dengan Model Pembelajaran Conceptual Understanding Procedures Berbantuan LKPD. Jurnal Pendidikan Fisika dan Teknologi. 1(3): 24-33.

Gummah, S., Soraya, L. H., Ahzan, S., \& Hardariyanti, H. (2014). Penerapan Model Pembelajaran Kooperatif Teknik Conceptual Understanding Procedures untuk Meningkatkan Hasil Belajar dan Aktivitas Siswa. Prisma Sains: Jurnal Pengkajian Ilmu dan
Pembelajaran Matematika dan IPA IKIP Mataram. 2(2): 310-315.

Hidayati, F. \& Sinulingga, K. (2015). Pengaruh Model Pembelajaran Conceptual Understanding Procedures (Cups) terhadap Hasil Belajar Siswa pada Materi Pokok Listrik Dinamis Di Kelas X Semester II SMA Negeri 1 Binjai TP 2014/2015. INPAFI (Inovasi Pembelajaran Fisika). 3(4): 59-66.

Ibrahim, I., Kosim, K., \& Gunawan, G. 2017. Pengaruh Model Pembelajaran Conceptual Understanding Procedures Berbantuan LKPD terhadap Kemampuan Pemecahan Masalah Fisika. Jurnal Pendidikan Fisika dan Teknologi. 1(3): 14-23.

Ismawati, I., Nugroho, P., \& Dwijananti, D.2014. Penerapan Model Pembelajaran Conceptual Understanding Procedures untuk Meningkatkan Curiosty dan Pemahaman Konsep Siswa. Jurnal Pendidikan Fisika Indonesia. 10: 2227.

Prastiwi, I., Soedjoko, E., \& Mulyono. 2014. Efektivitas Pembelajaran Conceptual Understanding Procedures untuk Meningkatkan Kemampuan Siswa pada Aspek Koneksi Matematika. Jurnal Kreano. 1(5): 41-47.

Sahidu, C. 2013. Penilaian Hasil Belajar. Mataram: Arga puji Press.

Setyosari, P. 2015. Metode Penelitian Pendidikan dan Pengembangan. Jakarta: Prenada Media Group.

Sugiyono. 2012. Statistika untuk Pendidikan. Bandung: Alfabeta.

Sundayanan, R. 2015. Statistika Penelitian Pendidikan. Bandung: Alvabeta.

Wena, M. 2014. Strategi Pembelajaran Inovatif Kontemporer. Jakarta Timur: PT Bumi Aksara.

Wulandari, M. L, Sutrio, S., \& Rahayu, S. 2017. Pengaruh Model Pembelajaran Conceptual Understanding Procedures terhadap Hasil Belajar 
Fisika Siswa Kelas XI SMA Negeri 5

Mataram Tahun Ajaran 2015/2016.

Jurnal Pendidikan Fisika dan

Teknologi. 2(3): 188-196. 